\title{
Texture of Butter from Cows with Different Milk Fatty Acid Compositions ${ }^{1}$
}

\author{
G. Bobe, E. G. Hammond, A. E. Freeman, G. L. Lindberg, ${ }^{2}$ and D. C. Beitz \\ Nutritional Physiology and Animal Breeding and Genetics Groups, \\ Departments of Animal Science and of Food Science and Human Nutrition, \\ lowa State University, Ames 50011-3150
}

\section{ABSTRACT}

Milk fatty acid composition and textural properties of butter are known to be affected by the cows' diets. We examined the phenotypic variation in milk fatty acid composition among cows fed the same diet to see if the variation was sufficient to produce butter with different textural properties. Ten cows were selected that tested higher $(n=5)$ or lower $(n=5)$ in their proportion of milk unsaturated fatty acids. Milk samples were collected a week after testing, and butter was prepared from the individual samples. Milk and butter samples were again analyzed for fatty acid composition. Butter at $5^{\circ} \mathrm{C}$ was evaluated by a sensory panel for spreadability and by a texture analyzer at both 5 and $23^{\circ} \mathrm{C}$ for hardness and adhesiveness. Milk and butter samples from cows with a more unsaturated milk fatty acid composition had a lower atherogenic index, and the butter samples were more spreadable, softer, and less adhesive. Thus, phenotypic variation in milk fatty acid composition among cows fed the same diet is sufficient to produce butter with different textural properties.

(Key words: butter texture, dairy cow, fatty acid composition)

Abbreviation key: $\mathbf{A I}=$ atherogenic index, $\mathbf{C L A}=$ conjugated linoleic acid.

\section{INTRODUCTION}

Dairy products, in particular butter, have been considered to increase the risk for cardiovascular diseases in humans because, in comparison to other lipid sources, they contain a higher proportion of lauric, my-

\footnotetext{
Received May 4, 2003.

Accepted June 3, 2003. edu.

Corresponding author: Donald C Beitz; e-mail: dcbeitz@iastate.

${ }^{1}$ Publication of the Iowa Agriculture and Home Economics Experiment Station, Ames, Project Number 3801. A preliminary report has been presented [J. Dairy Sci. 82(Suppl. 1): 17, 1999].

${ }^{2}$ Present address: Nutrition Professionals, 310 Golfview Drive, Albany, MN 56307.
}

ristic, and palmitic acids and a lower proportion of unsaturated fatty acids (Ulbricht and Southgate, 1991; Sacks and Katan, 2002). Ulbricht and Southgate (1991) proposed an atherogenic index (AI) for lipids as a dietary risk indicator for cardiovascular disease. The AI is the sum of the proportion in the fat of lauric and palmitic acids and four times myristic acid divided by the proportion of total unsaturated fatty acids. A higher ratio of saturated fatty acids also contributes to the hardness and poor spreadability of butter at refrigeration temperature (Edmondson et al., 1974; Taylor and Norris, 1977; Ashes et al., 1997). Brunner (1974) reported that $80 \%$ of the variation of butter texture can be explained by differences in milk fatty acid composition.

Nutrition has been considered to be the primary factor influencing milk fatty acid composition (Palmquist et al., 1993; Jensen, 2002). Feeding cows highly unsaturated oils such as canola (Bayourthe et al., 2000), fish (Baer et al., 2001; Ramaswamy et al., 2001), sunflower (Middaugh et al., 1988; Stegemann et al., 1992), safflower (Edmondson et al., 1974; Stegemann et al., 1992; Gonzalez et al., 2003), or extruded soybeans (Ramaswamy et al., 2001) increases the proportion of unsaturated fatty acids in milk and butter and causes the butter to be softer and more spreadable. Furthermore, consumption of dairy products from cows that were fed ruminally protected lipids decreased plasma cholesterol concentrations in humans (Noakes et al., 1996; Poppitt et al., 2002).

Factors such as genotype and stage of lactation, have been considered of minor importance in influencing milk fatty acid composition (Gibson, 1991; Palmquist et al., 1993; Jensen, 2002). But, Jaeck and Pabst (1990) reported differences in butter texture among herds fed similar diets. Significant heritability and repeatability estimates for milk fatty acid composition (Renner et al., 1974; Karijord et al., 1982; Bobe et al., 1996) suggest that sufficient variation exists among cows fed the same diet to produce butter with different textural properties and a more healthful fatty acid composition. Thus, the objective of the current study was to test whether the phenotypic variability of milk fatty acid composition 
among cows fed the same diet is sufficient to produce butter texture variations.

\section{MATERIALS AND METHODS}

\section{Experimental Design and Sample Collection}

Individual milk samples were obtained from 64 lactating dairy cows of the dairy teaching farm at Iowa State University to select for cows with low- or highAI milk. The cows were less than 150 DIM and belonged to several common dairy breeds (Ayrshire, Brown Swiss, Guernsey, Holstein, Jersey, and Milking Shorthorn). All cows were fed ad libitum twice daily (600 and $1700 \mathrm{~h}$ ) the same diet as a TMR, which had $62.4 \% \mathrm{DM}$ and contained, on a DM basis, $16.8 \% \mathrm{CP}, 17.9 \% \mathrm{ADF}$, $30.5 \% \mathrm{NDF}, 3 \%$ lipid, and $6.9 \%$ ash. The ingredients of the TMR were, on a DM basis, $7.4 \%$ alfalfa haylage, 9.6\% alfalfa hay, $31.5 \%$ corn silage, $24.2 \%$ high moisture corn, $13.0 \%$ corn gluten feed, $11 \%$ soybean meal, and $3.5 \%$ vitamin-mineral mix (Heart of Iowa, Gilbert, IA). The vitamin-mineral mix contained $15.3 \%$ $\mathrm{NaHCO}_{3} ; 4.3 \% \mathrm{MgO} ; 17.3 \% \mathrm{Ca}_{3}\left(\mathrm{PO}_{4}\right)_{2} ; 28.9 \% \mathrm{CaCO}_{3}$; $3.1 \%$ vitamin $\mathrm{A}, \mathrm{D}$, and $\mathrm{E}$ premix; $0.305 \%$ vitamin $\mathrm{A}$; $2.9 \%$ vitamin $\mathrm{E}$ premix; and $1.8 \%$ dairy trace minerals mix.

Fatty acid composition of milk from each cow was determined by forming butyl esters of fatty acids (Bobe et al., 1999). Briefly, $200 \mu \mathrm{l}$ of milk was suspended in $800 \mu \mathrm{l}$ of $n$-butanol in a glass vial with Teflon-lined screw cap. Next, $75 \mu \mathrm{l}$ of acetyl chloride was added while the tube was being vortexed. The vial was filled with $\mathrm{N}$ to prevent oxidation and then placed on a heating block at $100^{\circ} \mathrm{C}$ for $1.5 \mathrm{~h}$. After cooling the tubes to room temperature, the solution was neutralized with $\mathrm{K}_{2} \mathrm{CO}_{3}$, and the butyl esters were dissolved in hexane. The sample during the butyl ester-hexane phase was washed repeatedly with distilled water and then transferred into injection vials for analysis by gas chromatography.

Butyl esters were quantified by gas chromatography on a 30-m SPTM-2330 capillary column (Supelco, Bellefonte, PA) by using a Hewlett Packard (Palo Alto, CA) 5890A series II instrument equipped with a flame ionization detector and a model 3396A integrator. Carrier gas was helium at $3 \mathrm{ml} / \mathrm{min}$. The injector and detector were maintained at $250^{\circ} \mathrm{C}$, and the oven was programmed from $70^{\circ} \mathrm{C}$, after $4 \mathrm{~min}$, to $230^{\circ} \mathrm{C}$ at $20^{\circ} \mathrm{C} / \mathrm{min}$ and held at $230^{\circ} \mathrm{C}$ for $5 \mathrm{~min}$. An internal standard was added that contained $\mathrm{C}_{5: 0}$ for quantification of $\mathrm{C}_{4: 0}$ and $\mathrm{C}_{6: 0}, \mathrm{C}_{11: 0}$ for quantification of $\mathrm{C}_{8: 0}$ to $\mathrm{C}_{14: 0}$, and $\mathrm{C}_{19: 0}$ for quantification of $\mathrm{C}_{16: 0}$ and higher. External standards GLC73 and GLC79 (Nu-Chek Prep, Elysian, MN) were used to verify the accuracy of the analyses.
On the basis of AI, five cows with the highest AI indices (two Brown Swiss', one Guernsey, and two Jerseys) and five cows with the lowest AI indices (five Holsteins) were selected. The fatty acid composition data of these samples are not shown. One week after the analytical samples had been taken, milk from each of the 10 selected cows was collected separately for $1 \mathrm{~d}$ (1700 and $0500 \mathrm{~h}$ the following day) as well as $30 \mathrm{~kg}$ of herd milk from the bulk tank for a total of 11 milk samples.

\section{Butter Manufacture and Composition}

Each of the 11 milk samples was weighed and pasteurized individually at $63^{\circ} \mathrm{C}$ for $30 \mathrm{~min}$. Next, 30\% cream was separated at $20^{\circ} \mathrm{C}$ with an Elecrem Model 1 (Elecrem, Vanves, France). Babcock tests (Milk Industry Foundation, 1949) of milkfat concentrations were performed, and cream was stored overnight at $5^{\circ} \mathrm{C}$. An electric mixer (KitchenAid Model KHM9PWH, Troy, $\mathrm{OH})$ that was operated at the speed settings 4 or 5 at $5^{\circ} \mathrm{C}$ room temperature was used to make butter in duplicate churnings of $800 \mathrm{~g}$ of cream from each of the 11 milk samples for a total of 22 butter samples. Churning times varied between 34 and $53 \mathrm{~min}$ and were longer for milk of cows with high AI. After churning, sodium chloride was added to $1 \%$ manually, and the butter was adjusted to $80 \%$ fat with water as assayed with the modified Kohman method (Milk Industry Foundation, 1949). Butter samples were stored in closed plastic containers at $5^{\circ} \mathrm{C}$ until further analysis. For comparison, a commercial butter sample and four commercial margarine samples were purchased from a local grocery store and stored at $-20^{\circ} \mathrm{C}$ until used.

Fatty acid compositions of the milk samples from individual cows and from the bulk tank are determined as described earlier. Determination of fatty acid compositions of butter samples from individual cows and from the bulk tank and of the five commercial samples was similar to that of milk samples except that $10 \mathrm{mg}$ of butter or margarine instead of $200 \mu \mathrm{l}$ of milk was suspended in $800 \mu$ l of $n$-butanol. Fatty acid compositions of the milk, butter, and commercial samples are shown in Tables 1 and 2. Concentrations of trans-11 oleic acids are shown only for margarine samples in Table 2 because concentrations of trans-11 oleic acids in milk and butter samples were very small in comparison to concentrations of cis-9 oleic acids, so that the peaks for both fatty acids could not be distinguished from each other. Conjugated linoleic acids (CLA) coeluted with $\mathrm{C}_{20: 1}$ and, therefore, their concentrations are reported as their sum. Because the peak contains 75 to $85 \%$ CLA (Baer et al., 2001; Ramaswamy et al., 2001); hereafter, it will be referred simply as CLA. 


\section{Texture Analyses}

Hardness and adhesiveness of individual butter and margarine samples were determined in triplicates at sample temperatures of 5 and $23^{\circ} \mathrm{C}$ by using a TA-XT2 texture analyzer (Stable Micro Systems, London, UK). A 5-mm layer of the sample was removed from the surface of the sample before measurement. A $40^{\circ}$ conical probe was lowered at $1 \mathrm{~mm} / \mathrm{s}$ to a depth of $12 \mathrm{~mm}$ from the sample surface and then was withdrawn at the same speed. Data acquisition began at $5 G$ of probe force. The penetration force (in $G$ ) was reported as hardness, and the negative force-time value (in $G \times \mathrm{s}$ ) generated during probe withdrawal was reported as adhesiveness. Spreadabilities of butter and margarine samples at $5^{\circ} \mathrm{C}$ were determined by 20 untrained panelists who evaluated five samples on each of $5 \mathrm{~d}$ on a continuous 14-cm scale from 0 (easily spreadable as the tub margarine of brand 1, which was the softest sample in the current study as determined with the TA-XT2 texture analyzer) to 14 (difficult to spread as the hardest butter sample in the current study as determined with the TA-XT2 texture analyzer). Both extreme samples were available to the panelists for comparison.

\section{Statistical Analyses}

Data for milk and butter fatty acid composition were analyzed by using the mixed models procedures of SAS Version 8.2 (2001). The fixed variables were AI index of milk samples collected from the same cow $1 \mathrm{wk}$ before butter manufacture (low or high), type of dairy product (milk or butter), and their interaction. A completely unrestricted variance-covariance matrix was used to account for correlations between variables of samples from the same cow. Effects of AI index (low vs. high), type of dairy product (milk vs. butter), and AI index in milk and butter were determined by using a $t$-test. A similar model was used for statistical analysis of hardness and adhesiveness of butter, except that type of dairy product was replaced by butter temperature (5 or $23^{\circ} \mathrm{C}$ ). Because of mathematical convergence problems, spreadability data of butter from each cow were averaged. The means of the low- and high-AI groups were compared by using analysis of variance in PROC GLM.

\section{RESULTS AND DISCUSSION}

Milk from low-AI cows had a 47\% lower AI value than did high-AI cows (Table 1). These differences in AI are similar to those reported for feeding unsaturated oils (Edmonson et al., 1974; Middaugh et al., 1988; Stegeman et al., 1992; Bayourthe et al., 2000; Baer et al., 2001; Ramaswamy et al., 2001; Gonzalez et al., 2003). Cows with low-AI values for milk had a $15 \%$ lower proportion of saturated fatty acids and a $44 \%$ higher proportion of monounsaturated fatty acids in milk fat (Table 1). Specifically, concentrations of CLA and the monounsaturated fatty acids palmitoleic and oleic acids were higher, and concentrations of primarily de novosynthesized fatty acids $\left(\mathrm{C}_{6: 0}\right.$ to $\left.\mathrm{C}_{16: 0}\right)$ were lower (Table 1). The smaller proportion of $\mathrm{C}_{6: 0}$ to $\mathrm{C}_{16: 0}$ and the higher proportion of CLA (Table 1) suggest that cows with low AI have lower de novo fatty acid synthesis (Palmquist et al., 1993; Jensen, 2001), which is similar to that for cows fed a diet supplemented with unsaturated oils (Ashes et al., 1997). This hypothesis is supported by the observation that cows in the low-AI group produced less milk (25.1 vs. $31.5 \mathrm{~kg} / \mathrm{d} ; P=0.02)$ but similar amounts of fat $(1.09 \mathrm{vs} .1 .14 \mathrm{~kg} / \mathrm{d} ; P=0.75)$ than did cows in the high-AI group.

In butter samples, the proportions of CLA and butyric and oleic acids were lower and the proportions of myristic acid tended to be higher than in their respective milk samples (Table 1). There were, however, only minor changes in significance values for differences between milk and butter from the low- and high-AI group (Table 1). These results suggest that only minor changes in milk fatty acid composition occur during the butter manufacturing process, which has been reported previously (Baer et al., 2001). The fatty acid compositions of the bulk tank and the commercial butter samples were between those of the low- and high-AI group (Table 2 ), indicating that the milk samples of the selected cows were representative.

Consumption of dairy products with lower AI values decreases concentrations of total and low-density lipoprotein cholesterol in blood plasma from humans in comparison to consumption of commercial dairy products (Noakes et al., 1996; Poppitt et al., 2002). Because of the documented beneficial health effects, there is a potential niche market for dairy products with lower AI (Gibson, 1991). The margarine samples (Table 2) had lower AI than did butter from low-AI cows (Table 1) but also had much higher concentrations of transoleic acids, which increase concentrations of total and low-density lipoprotein cholesterol (Ratnayake et al., 1998). Edmondson et al. (1974) reported that milk fat with lower AI values develops an oxidized flavor, which is a potential disadvantage of low-AI dairy products. But most studies, including this study, could detect no differences in butter flavor between samples that differ in fatty acid saturation (Middaugh et al., 1988; Stegeman et al., 1992; Baer et al., 2001; Ramaswamy et al., 2001).

At $5^{\circ} \mathrm{C}$, butter samples from the low-AI group were $38 \%$ softer, $35 \%$ less adhesive, and $46 \%$ more spreadable than were butter samples from the high-AI group (Table 3). Increasing butter temperature de- 
Table 1. Least squares means and significance of differences in fatty acid composition of milk and butter samples from cows that differ in atherogenic index (AI).

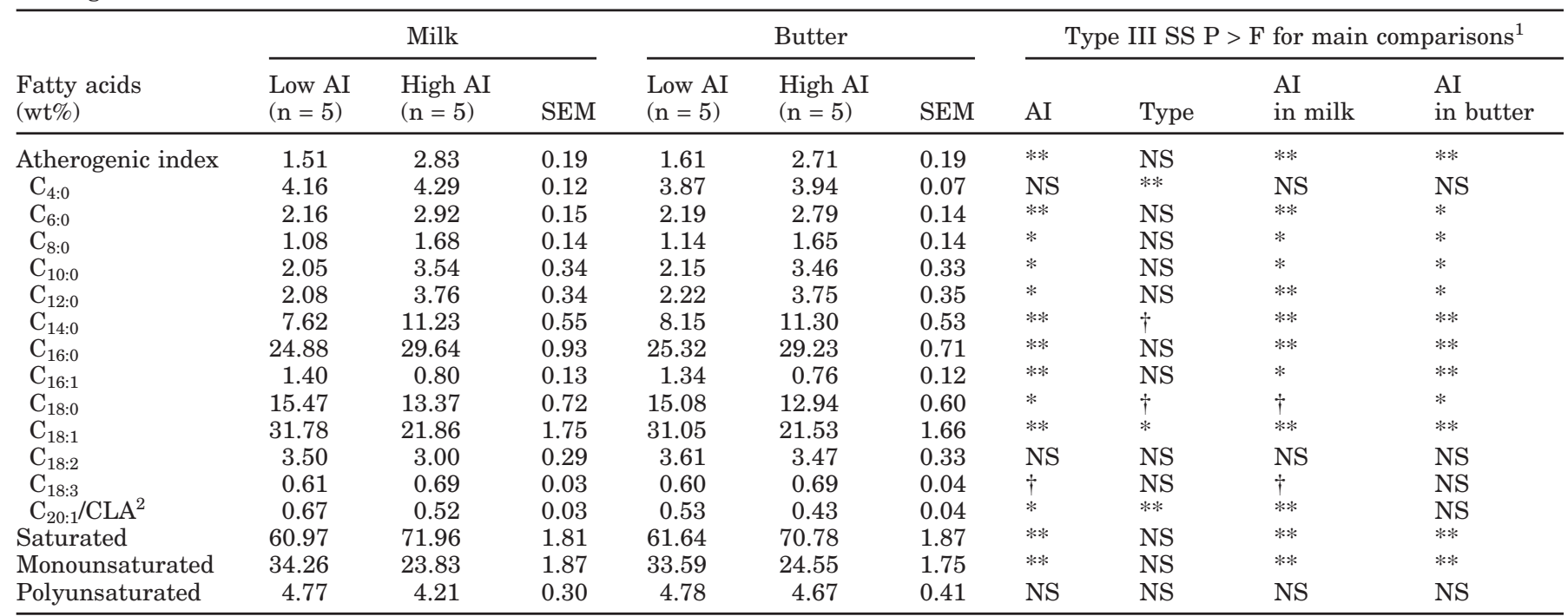

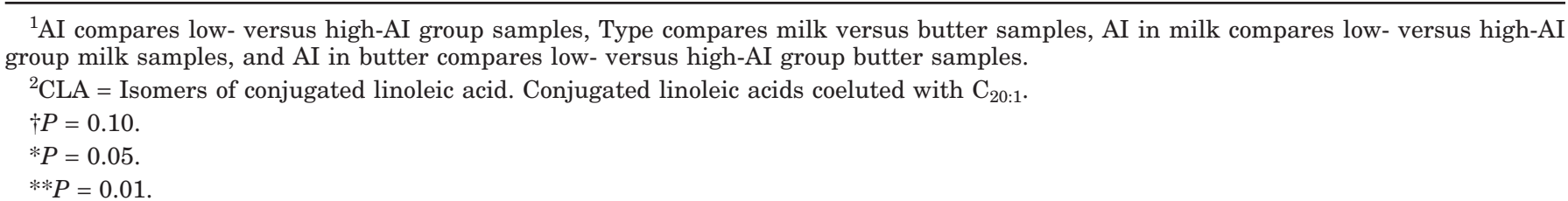

creased hardness and adhesiveness but did not affect were $46 \%$ softer and $26 \%$ less adhesive. To a similar the significance of difference between low- and high-AI milk. At $23^{\circ} \mathrm{C}$, butter samples from the low-AI group extent, butter from cows that are fed additional unsaturated oils is softer at refrigeration and room tempera-

Table 2. Fatty acid composition of different margarine and butter samples arranged according to their atherogenic index $(\mathrm{AI})$.

\begin{tabular}{|c|c|c|c|c|c|c|c|}
\hline \multirow[b]{3}{*}{$\begin{array}{l}\text { Fatty acids } \\
(\text { wt } \%)\end{array}$} & \multicolumn{4}{|c|}{ Commercial margarine } & \multicolumn{3}{|c|}{ Butter } \\
\hline & \multicolumn{2}{|c|}{ Brand 1} & \multicolumn{2}{|c|}{ Brand 2} & \multirow{2}{*}{$\begin{array}{l}\text { Commercial } \\
\text { Stick } \\
(\mathrm{n}=1)\end{array}$} & \multicolumn{2}{|c|}{ Bulk tank } \\
\hline & $\begin{array}{l}\text { Tub } \\
(\mathrm{n}=1)\end{array}$ & $\begin{array}{l}\text { Stick } \\
(\mathrm{n}=1)\end{array}$ & $\begin{array}{l}\text { Tub } \\
(\mathrm{n}=1)\end{array}$ & $\begin{array}{l}\text { Stick } \\
(\mathrm{n}=1)\end{array}$ & & $\begin{array}{l}\text { Milk } \\
(\mathrm{n}=1)\end{array}$ & $\begin{array}{l}\text { Butter } \\
(\mathrm{n}=1)\end{array}$ \\
\hline Atherogenic index & 0.12 & 0.13 & 0.13 & 0.13 & 2.03 & 2.28 & 2.31 \\
\hline $\mathrm{C}_{4: 0}$ & trace & trace & trace & trace & 3.81 & 4.37 & 4.14 \\
\hline $\mathrm{C}_{6: 0}$ & trace & trace & trace & trace & 2.31 & 2.68 & 2.61 \\
\hline $\mathrm{C}_{8: 0}$ & trace & trace & trace & trace & 1.29 & 1.48 & 1.44 \\
\hline $\mathrm{C}_{10: 0}$ & trace & trace & trace & trace & 2.73 & 2.89 & 2.89 \\
\hline $\mathrm{C}_{12: 0}$ & trace & trace & trace & trace & 3.01 & 3.05 & 3.15 \\
\hline $\mathrm{C}_{14: 0}$ & 0.14 & 0.24 & 0.18 & 0.16 & 9.85 & 10.39 & 10.65 \\
\hline $\mathrm{C}_{16: 0}$ & 9.75 & 10.15 & 10.12 & 9.82 & 27.32 & 28.61 & 28.65 \\
\hline $\mathrm{C}_{16: 1}$ & trace & trace & 0.11 & trace & 1.08 & 1.13 & 1.15 \\
\hline $\mathrm{C}_{18: 0}$ & 6.21 & 6.32 & 6.93 & 8.53 & 13.68 & 12.70 & 12.41 \\
\hline $\mathrm{C}_{\text {trans-11 18:1 }}$ & 7.76 & 15.07 & 7.84 & 16.58 & $\mathrm{ND}^{1}$ & ND & ND \\
\hline $\mathrm{C}_{c i s ~ 18: 1}$ & 27.24 & 27.65 & 23.98 & 30.63 & 27.30 & 25.42 & 25.27 \\
\hline $\mathrm{C}_{18: 2}$ & 47.33 & 39.31 & 41.43 & 29.07 & 3.25 & 2.94 & 3.18 \\
\hline $\mathrm{C}_{18: 3}$ & 0.80 & 0.84 & 6.75 & 4.13 & 0.55 & 0.61 & 0.55 \\
\hline $\mathrm{C}_{20: 1} / \mathrm{CLA}^{2}$ & 0.23 & trace & 0.15 & trace & 0.63 & 0.55 & 0.42 \\
\hline Saturated & 16.65 & 17.13 & 18.41 & 19.59 & 65.61 & 67.88 & 67.75 \\
\hline Monounsaturated & 35.00 & 42.73 & 33.26 & 47.21 & 29.96 & 28.00 & 27.93 \\
\hline Polyunsaturated & 48.36 & 40.15 & 48.33 & 33.20 & 4.42 & 4.11 & 4.32 \\
\hline
\end{tabular}

${ }^{1} \mathrm{ND}=$ not determined. trans-11 oleic acids coeluted with cis-9 oleic acids and their concentrations are included in cis oleic acids.

${ }^{2} \mathrm{CLA}=$ Isomers of conjugated linoleic acid. Conjugated linoleic acids coeluted with $\mathrm{C}_{20: 1}$. 
Table 3. Least squares means and significance of differences in texture ${ }^{1}$ of butter at different temperatures from cows that differ in atherogenic index $(\mathrm{AI})$.

\begin{tabular}{|c|c|c|c|c|c|c|c|c|c|c|}
\hline \multirow[b]{2}{*}{ Texture } & \multicolumn{3}{|c|}{$5^{\circ} \mathrm{C}$ butter temperature } & \multicolumn{3}{|c|}{$23^{\circ} \mathrm{C}$ butter temperature } & \multicolumn{4}{|c|}{$\begin{array}{c}\text { Type III SS } P>F \text { for main } \\
\text { comparisons }{ }^{2}\end{array}$} \\
\hline & $\begin{array}{l}\text { Low AI } \\
(\mathrm{n}=5)\end{array}$ & $\begin{array}{l}\text { High AI } \\
(\mathrm{n}=5)\end{array}$ & SEM & $\begin{array}{l}\text { Low AI } \\
(\mathrm{n}=5)\end{array}$ & $\begin{array}{l}\text { High AI } \\
(\mathrm{n}=5)\end{array}$ & SEM & $\mathrm{AI}$ & Temperature & $\begin{array}{l}\text { AI } \\
\text { at } 5^{\circ} \mathrm{C}\end{array}$ & $\begin{array}{l}\mathrm{AI} \\
\text { at } 23^{\circ} \mathrm{C}\end{array}$ \\
\hline Hardness (g) & 651 & 1044 & 111 & 11.5 & 21.2 & 3.0 & $*$ & $* *$ & $*$ & * \\
\hline Adhesiveness ( $\mathrm{g} \times \mathrm{s}$ ) & 1094 & 1683 & 131 & 98.6 & 133.6 & 7.4 & $* *$ & ** & $* *$ & $* *$ \\
\hline Spreadability (scale 0-14) & 10.88 & 7.44 & 0.54 & $\mathrm{ND}^{3}$ & ND & ND & $* *$ & ND & $* *$ & ND \\
\hline
\end{tabular}

${ }^{1}$ Hardness and adhesiveness of individual butter samples were determined in triplicates at 5 and $23^{\circ} \mathrm{C}$ sample temperature by using a TA-XT2 texture analyzer. Spreadabilities of individual butter samples at $5^{\circ} \mathrm{C}$ sample temperature were determined by 20 panelists using a continuous scale from 0 (easily spreadable) to 14 (difficult to spread).

${ }^{2} \mathrm{AI}$ compares low- versus high-AI group samples, Temperature compares butter samples at 5 versus $23^{\circ} \mathrm{C}$, AI at $5^{\circ} \mathrm{C}$ compares low- versus high-AI group butter samples at $5^{\circ} \mathrm{C}$, and $\mathrm{AI}$ at $23^{\circ} \mathrm{C}$ compares low- versus high-AI group butter samples at $23^{\circ} \mathrm{C}$.

${ }^{3} \mathrm{ND}=$ not determined.

$* P=0.05$.

$* * P=0.01$.

ture than is butter from control-fed cows (Middaugh et al., 1988; Stegeman et al., 1992; Baer et al., 2001; Ramaswamy et al., 2001). To our knowledge, adhesiveness and spreadability data on butters have not been reported previously. These results indicate that the variation among cows fed the same diet is sufficient to manufacture butter with different textural properties and with differences similar in magnitude to those produced by variation in diet composition.

Commercial margarine samples were numerically softer and less adhesive at $5^{\circ} \mathrm{C}$ than were butter samples (Table 4), which is similar to results of other studies (Edmondson et al., 1974; Taylor and Norris, 1977). At $23^{\circ} \mathrm{C}$, however, the texture properties of margarine samples were both higher and lower than those of butter samples (Table 4). Additionally, the textural properties of the bulk tank and the commercial butter sample were between those of the low- and high-AI groups at $5^{\circ} \mathrm{C}$ but not at $23^{\circ} \mathrm{C}$ (Table 4). Taylor and Norris (1977) reported also that at room temperature the textural properties of butter are less closely associated with the milk fatty acid composition than at $5^{\circ} \mathrm{C}$.

Commercial production of large quantities of low-AI fluid milk and dairy products could be achieved by two ways. On a short-term basis, low-AI cows could be identified from commercial herds. In a preliminary study, the authors estimated that $22 \%$ of the variation of AI within a herd could be explained by the variation between cows. This finding is supported by repeatability estimates of 0.25 to 0.40 and 0.10 to 0.23 for concentrations of major fatty acids in milk fat within herd (Bobe et al., 1996) and overall (Karijord et al., 1982), respectively. On a long-term basis, herds producing low-AI milk could be established by genetic selection, because heritability estimates for concentrations of major fatty acids in milk fat are 0.08 to 0.25 and 0.06 to 0.17 within herd (Bobe et al., 1996) and overall (Karijord et al., 1982), respectively.

Table 4. Textural properties ${ }^{1}$ at 5 and $23^{\circ} \mathrm{C}$ sample temperatures of different margarine and butter samples arranged according to their atherogenic index.

\begin{tabular}{|c|c|c|c|c|c|}
\hline \multirow[b]{2}{*}{ Sample $(\mathrm{n}=1)$} & \multicolumn{2}{|c|}{$\begin{array}{l}\text { Hardness } \\
(\mathrm{g})\end{array}$} & \multicolumn{2}{|c|}{$\begin{array}{l}\text { Adhesiveness } \\
(\mathrm{g} \times \mathrm{s})\end{array}$} & \multirow{2}{*}{$\begin{array}{c}\text { Spreadability } \\
\text { (Scale 0-14) } \\
5^{\circ} \mathrm{C}\end{array}$} \\
\hline & $5^{\circ} \mathrm{C}$ & $23^{\circ} \mathrm{C}$ & $5^{\circ} \mathrm{C}$ & $23^{\circ} \mathrm{C}$ & \\
\hline \multicolumn{6}{|c|}{ Commercial margarine: } \\
\hline Brand 1 tub & 44 & 9.1 & 190 & 79.7 & 0.57 \\
\hline Brand 1 stick & 138 & 21.5 & 481 & 173.2 & 1.52 \\
\hline Brand 2 tub & 61 & 8.6 & 222 & 64.5 & 0.69 \\
\hline Brand 2 stick & 227 & 27.6 & 840 & 214.4 & 2.39 \\
\hline \multicolumn{6}{|l|}{ Butter: } \\
\hline Commercial stick & 600 & 18.5 & 1330 & 125.1 & 8.62 \\
\hline Bulk tank & 1052 & 13.4 & 1617 & 89.3 & 10.59 \\
\hline
\end{tabular}

${ }^{1}$ Hardness and adhesiveness of individual butter samples were determined in triplicates at 5 and $23^{\circ} \mathrm{C}$ sample temperature by using a TA-XT2 texture analyzer. Spreadabilities of individual butter samples at $5^{\circ} \mathrm{C}$ sample temperature were determined by 20 panelists using a continuous scale from 0 (easily spreadable) to 14 (difficult to spread). 
In conclusion, the current study demonstrates that the variation in milk fatty acid composition among cows fed the same diet is sufficient to produce butter with different textural properties. Selection of individual cows within a herd or breeding programs could be used to alter fatty acid composition to a profile, which is more beneficial for human health.

\section{ACKNOWLEDGMENTS}

The authors thank the USDA Center for Designing Foods to Improve Nutrition (Ames, IA) for financial support. Appreciation is extended to the management of the Iowa State University Dairy Teaching Herd for provision of milk samples of cows, to $\mathrm{M}$. Reuber for technical assistance with the milk processing equipment, to E. M. Polkanova and S. Zimmerman for assistance in preparation and analysis of butter samples, and to the sensory panelists.

\section{REFERENCES}

Ashes, J. R., S. K. Gulati, and T. W. Scott. 1997. Potential to alter the content and composition of milk fat through nutrition. J. Dairy Sci. 80:2204-2212.

Baer, R. J., J. Ryali, D. J. Schingoethe, K. M. Kasperson, D. C. Donovan, A. R. Hippen, and S. T. Franklin. 2001. Composition and properties of milk and butter from cows fed fish oil. J. Dairy Sci. 84:345-353.

Bayourthe, C., F. Enjalbert, and R. Moncoulon. 2000. Effects of different forms of canola oil fatty acid plus canola meal on milk composition and physical properties of butter. J. Dairy Sci. 83:690-696.

Bobe, G., A. E. Freeman, D. C. Beitz, and G. L. Lindberg. 1996. Estimation of heritabilities for amounts of individual proteins and fatty acids in milk of Holstein cattle. J. Anim. Sci. 74(Suppl. 1):26.

Bobe, G., D. C. Beitz, A. E. Freeman, and G. L. Lindberg. 1999. Associations among individual proteins and fatty acids in bovine milk as determined by correlations and factor analyses. J. Dairy Res. 66:523-536.

Brunner, J. B. 1974. Physical equilibria in milk: The lipid phase. Pages 447-602 in Fundamentals of Dairy Chemistry. 2nd ed. B. H. Webb, A. H. Johnson, and J. A. Alford, ed. AVI, Westport, CT.

Edmondson, L. F., R. A. Yoncoskie, N. H. Rainey, F. W. Douglas, Jr., and J. Bitman. 1974. Feeding encapsulated oils to increase the polyunsaturation in milk and meat fat. J. Am. Oil Chem. Soc. $51: 72-76$.
Gibson, J. P. 1991. The potential for genetic change in milk fat composition. J. Dairy Sci. 74:3258-3266.

Gonzalez, S., S. E. Duncan, S. F. O'Keefe, S. S. Sumner, and J. H. Herbein. 2003. Oxidation and textural characteristics of butter and ice cream with modified fatty acid profiles. J. Dairy Sci. 86:70-77.

Jaeck, W., and K. Pabst. 1990. Field investigations on feeding of cows and milk fat quality. Kieler Milchwirtschaftl. Forschungsber. 42:281-296.

Jensen, R. G. 2002. Invited review: The composition of bovine milk lipids: January 1995 to December 2000. J. Dairy Sci. 85:295-350.

Karijord, Ø., N. Standal, and O. Syrstad. 1982. Sources of variation in composition of milk fat. Z. Tierz. Zuechtungsbiol. 99:81-93.

Middaugh, R. P., R. J. Baer, D. P. Casper, D. J. Schingoethe, and S. W. Seas. 1988. Characteristics of milk and butter from cows fed sunflower seeds. J. Dairy Sci. 71:3179-3187.

Milk Industry Foundation. 1949. Pages 187-245 in Laboratory Manual. Methods of Analysis of Milk and Its Products. 2nd ed. Milk Industry Foundation, Washington, DC.

Noakes, M., P. J. Nestel, and P. M. Clifton. 1996. Modifying the fatty acid profile of dairy products through feedlot technology lowers plasma cholesterol of humans consuming the products. Am. J. Clin. Nutr. 63:42-46.

Palmquist, D. L., A. D. Beaulieu, and D. M. Barbano. 1993. Feed and animal factors influencing milk fat composition. J. Dairy Sci. 76:1753-1771.

Poppitt, S. D., G. F. Keogh, T. B. Mulvey, B. H. McArdle, A. K. H. MacGibbon, and G. J. S. Cooper. 2002. Lipid-lowering effects of a modified butter-fat: a controlled intervention trial in healthy man. Eur. J. Clin. Nutr. 56:64-71.

Ramaswamy, N., R. J. Baer, D. J. Schingoethe, A. R. Hippen, K. M. Kasperson, and L. A. Whitlock. 2001. Composition and flavor of milk and butter from cows fed fish oil, extruded soybeans, or their combination. J. Dairy Sci. 84:2144-2151.

Ratnayake, W. M. N., G. Pelletier, R. Hollywood, S. Bacler, and D. Leyte. 1998. trans-Fatty acids in Canadian margarines: Recent trends. J. Am. Oil Chem. Soc. 75:1587-1594.

Renner, E., and U. Kosmack. 1974. Genetic aspects concerning fatty acid composition of milk fat. 2. Fatty acid pattern of milk from progeny groups. Zuechtungskunde 46:217-226.

Sacks, F. M., and M. Katan. 2002. Randomized clinical trials on the effects of dietary fat and carbohydrate on plasma lipoproteins and cardiovascular disease. Am. J. Med. 113:13S-24S.

SAS User's Guide: Statistics, Version 8.2. 2001. SAS Inst., Inc., Cary, NC.

Stegeman, G. A., R. J. Baer, D. J. Schingoethe, and D. P. Casper. 1992. Composition and flavor of milk and butter from cows fed unsaturated dietary fat and receiving bovine somatotropin. J. Dairy Sci. 75:962-970.

Taylor, M. W., and R. Norris. 1977. The physical properties of dairy spreads. N.Z. J. Dairy Sci. Technol. 12:166-170.

Ulbricht, T. L. V., and D. A. T. Southgate. 1991. Coronary heart disease: seven dietary factors. Lancet 338:985-992. 